\title{
DEFINING AND THEORIZING TERRORISM: A GLOBAL ACTOR-CENTERED APPROACH
}

\author{
Omar Lizardo \\ Department of Sociology \\ University of Notre Dame \\ olizardo@nd.edu
}

\begin{abstract}
Arriving at a consensual definition of the phenomenon of terrorism has been a particularly difficult undertaking. Some definitions are either too specific or too vague, concentrating on some essential "terrorist" aspect of the actions, strategies, or types of non-state organizations that engage in terrorism. In this paper I draw on global approaches from international relations and world systems theories to propose a definition of terrorism that skirts these issues by concentrating on terrorist actors rather than terrorist behavior. I argue that this approach has several advantages, including the dissolution of several empirical and analytical problems produced by more essentialist definitions, and the location of terrorism within a two dimensional continuum of collective-violence phenomena in the international system which discloses important theoretical insights. I proceed to examine the characteristics of terrorism by comparing it with other forms of violence in the international system. I propose that terrorism may be part of the cycles and trends of unrest in the world system, responding to the same broad families of global dynamics as other forms of system-level conflict.
\end{abstract}

\section{INTRODUCTION}

It is no secret that arriving at a consensual definition of terrorism is a difficult task. Some might say that constructing a characterization of terrorism that would be satisfactory for everyone is a downright impossible undertaking. It is much easier to point out the flaws in extant conceptions and usages of the term than to come up with a definition that would be free of those same faults, while being comprehensive enough to be both acceptable to most lay observers and useful for the conduct of academic research on the subject. Taking a birds-eye view of the field, it is clear what is wrong with current characterizations of terrorism: they are either too specific or too vague, they concentrate on particular (and theoretically arbitrary) aspects of the phenomenon while deemphasizing others, or are too normatively oriented, mixing up descriptive and prescriptive terminology.

Using inconsistent definitions of the term is not helpful for a variety of reasons (see Gibbs 1989:329; Goodwin 2006:2027-2028). First, semantic vagueness has served to make it 
difficult for researchers to consistently study the phenomenon, as people use the same term to refer to a wide variety of events, ranging from state oppression and killing of civilians, to shootings in public places by lone gunmen. Second, normative definitions of the term attempt to arrive at a characterization of terrorism in the abstract without either trying to a) look at terrorist phenomena as examples of a more inclusive category of events or in relation to other forms of political violence or b) define terrorism using a strategy in which it is contrasted with other phenomena that already have relatively consensually established definitions. In this respect, "the use of legal or a moral model may obscure important variables that influence the development of terrorist groups and terrorist actions" (Ruby 2002:13). Thus, normative definitions do not help in the task of situating the phenomenon of terrorism as a possible structural variant of collective action phenomena that are better understood.

In this paper, I argue that much can be gained from following this latter route. In what follows, I will attempt to clarify and expand the definition of the phenomenon of terrorism by situating it within the larger theoretical framework of the study of collective violence from an international relations and world systemic point of view (Arrighi and Silver 1999; Bornschier and Chase-Dunn 1998). The advantage of this approach is that terrorism can be seen to occupy an important place in the collection of "species" of collective violence phenomena that can be observed in the international arena - and for which global correlates have been theorized and measured (Goldstein 1988) - ranging from all-out interstate major power wars, to civil wars and riots (the more established topics of studies of collective violence in political science and sociology).

I do this by taking an actor-centered approach to the definition and theorization of terrorism. From this perspective, the most important consideration in typologizing terrorism is: what type of actor-given the current institutional understandings and procedures that define what actors are in the interstate system (Meyer, Boli, and Thomas 1994) -initiates the action and what type of actor is the target? This approach allows us to define a two-dimensional space of possible forms of collective violence, in which different variants of terrorism occupy an important, yet under-researched region. I propose that this definition of terrorism is advantageous because it is neutral as to issues of motivation, grievances, and the historically specific standards of moral valuation of terrorist violence.

This paper is organized as follows: in the next section, I introduce the actor-centered approach by way of arguing against essentialist definitions of terrorism. In section three, I introduce my own definition of terrorism using the case of the relationship between terrorism and the nation-state as a backdrop. Section four introduces a new typology of actors and violent interaction in the interstate system, which includes terrorism in the same framework as civil wars, ethnic conflict and global warfare. Finally, section 5 discusses the theoretical implications of analyzing terrorism from the perspective of the dominant contemporary approaches to the analysis of systemic conflict in international relations and world-systems theories.

\section{ACTORS, LEGITIMACY AND TERRORISM: IS 'TERROR' THE DEFINING FEATURE OF TERRORISM?}

Most definitions of terrorism attempt to characterize the phenomenon by focusing on the apparent goal of terrorist organizations, which most analysts presume (but seldom empirically establish in 


\section{JOURNAL OF WORLD-SYSTEMS RESEARCH}

an objective manner) is to inflict, or spread a sense of "terror" or general psychological distress in their victims for politico-ideological purposes. Terrorism from this point of view is simply the most adequate "means" to the actualization of those goals. From this perspective, it is taken for granted that the intended aim of terrorists is to terrorize, and thus most people attempt to define what terrorism is by defining what terrorizing is, which usually involves some mention of "intimidation," "influence" and "coercion" (Schmid and Jongman 1988).

However, because what counts as acceptable practices of violence and therefore what terrorizes a particular population may exhibit wide historical and/or cultural variation (Foucault 1977), these attempts to define terrorism ultimately serve as grist to the pessimist nominalism which throws up its hands and declares any attempt at a definition of terrorism impossible. I argue that if we are to come up with an operationally and theoretically justifiable definition of terrorism, the focus should not be on what "terror" could be. After all, as most normativists point out, this is the value-laden term that was selected and popularized by modern (non-state) terrorism's first victims - Western European states in the second half of the $19^{\text {th }}$ century-and as such focusing on the terror component as an essential feature of what some coherent set of "terrorist" actors strive for may be theoretically misleading (Tilly 2004:5). However, in order to argue that the goal of "terrorizing" should not be used as the primary criterion with which to characterize the phenomenon of terrorism, I will propose a sociological explanation as to why so many terrorist organizations appear to engage in actions apparently contrived for no purpose other than to "terrorize" a particular audience. But first let us examine some extant definitions of the phenomenon.

\section{Definitions}

A lot of the theoretical work on terrorism revolves around definitions (see the discussions in Cooper 2001; Gibbs 1989; Hoffman 1998: 13-15; Jenkins 2001; Ruby 2002; Schmid and Jongman 1988: 32-38; for a collection of definitions, see Goodwin 2006, table 1). For example, for Enders and Sandler "Terrorism is the premeditated use or threat of use of extranormal violence or brutality by subnational groups to obtain a political, religious, or ideological objective through intimidation of a huge audience, usually not directly involved with the policy making that the terrorists seek to influence" (2002:145-146, italics added). The U.S. Department of State defines terrorism as "politically motivated violence perpetrated against noncombatant targets by subnational groups or clandestine agents, usually intended to influence an audience" (quoted in Ruby 2002:10). This is similar to Chomsky's (2001:19, italics added) definition: "Terrorism is the use of coercive means aimed at populations in an effort to achieve political, religious, or other aims". Tilly (2004:5, italics added) tell us that terrorism is "asymmetrical deployment of threats and violence against enemies using means that fall outside the forms of political struggle routinely operating within some current regime." Stern (1999:30, italics added) defines terrorism as "an act or threat of violence against non-combatants, with the objective of intimidating or otherwise influencing an audience or audiences." Peter Chalk offers a definition similar to the ones above when he conceptualizes terrorism as "the systematic use of illegitimate violence that is employed by sub-state actors as means of achieving specific political objectives, these goals differing according to the group concerned" (Chalk 1999:151, italics added).

Notice that most of these definitions - with the exception of Chomsky and the State Department-point to some ineffable "extranormal", brutal and extraordinary aspect of terrorist 
violence, which is designed to mostly to "intimidate" civilian audiences. Surely the term "extranormal" cannot in this context be used to imply that terrorists are more violent than state armies. As has been amply demonstrated in various historical studies (e.g. Oliverio 1998), not only have state-affiliated agents been responsible for the bulk of civilian deaths not caused by famine, disease or natural disasters throughout history, but modern terrorism itself began as a military tactic designed to subdue the enemy during warfare. It was used to great effect during the Northern incursion into the South in the American Civil War as noted by Carr (2001), even if the name comes from the French state persecution of civilians after the revolution of 1789. It is in this sense that terrorism "is one of the oldest techniques of psychological warfare" (Wilkinson 1977:49).

Thus, terrorist activities cannot be characterized and differentiated-and therefore terrorism as a form of political violence cannot be defined-by pointing to their specific viciousness and/or brutality, since these have been exceeded during the course of more legitimate forms of warfare, as in the allied bombings of Dresden (Graham 2004). In this respect it is important to separate terror as a psychological state of affairs (or as a goal of a particular violence producing organization) from terrorism as a specific form of politico-military interaction between two actors (O'Sullivan 1986).

Extranormal, therefore can only here be taken to mean illegitimate (Gibbs 1989:330), illegal or as Tilly puts it, "outside of the routine forms of political [and I would add military] struggle" (2004: 5). In O'Sullivan's (1986:5) words, terrorists resort to "methods which...subvert or ignore the requirements of domestic and international law." This is consistent with an understanding of institutions as rules that assign cognitively constituted actors to certain types of actions and preclude certain actors from engaging in certain types of actions (March and Olsen 1989). However, socially agreed upon definitions of legality evolve and vary through time and space (Durkheim 1997[1933]), which would make a definition which focused on the legality of the type of violence subject to the charge of nominalism and historical relativism. In this respect, even though "brutality" or its status as "extranormal" is not a useful criterion with which to arrive at a useful definition of terrorism, Jenkin's (2001) and Tilly's (2004) suggestion that what is characteristic of terrorism is its very illegitimacy and non-routineness appears as a more promising — and less essentialist — pathway.

\section{Constraints on Terrorist Organizations: Legitimacy and the State Monopoly of Violence}

In order to begin tackling the question of the theoretical justification of excluding the explicit goal of "terrorizing" a given audience as a defining feature of terrorism, it is important to make an important distinction between two forms of collective conflict. I refer to the difference between ritualized, legitimated and symmetric forms of organized collective violence such as interstate war, and illegitimate, asymmetric interactions such as those that are usually classified as terrorist attacks. In the former, both parties recognize implicit rules of engagement (Hoffman 1998:34-36) and hold each other accountable for following them; in the latter, one partner (usually the stateactor that is the target), does not recognize the other as a legitimate partner in violence and as a rule refuses to define their interaction as a properly recognized episode of warfare.

It is surprising how little the question of (cognitive) legitimacy-as opposed to say, illegality - enters into the discussion (and definitions) of terrorism. In this respect, it is possible to argue that the apparent inability to "comprehend" terrorist actions-both on part of lay and 


\section{JOURNAL OF WORLD-SYSTEMS RESEARCH}

academic audiences - is directly tied to the fact that both terrorist organizations as actors and the output of those organizations as actions and events are not considered legitimate forms of intercourse in the international arena. Institutionalization is important, because it pertains both to how entities and their actions are perceived and responded to by other entities in their immediate environment, and how the behavior of actors is constrained in their interactions with other entities (Meyer, Boli, and Thomas 1994). This is because institutions provide observers with cognitive limits as to what makes sense and what falls outside of the "possible" and the expected (March and Olsen 1989; Scott 2001).

Thus, it is possible to argue that illegitimate entities and actions - especially when those entities violate our most well established expectations-will always have trouble finding a coherent place in most established frameworks for understanding the world, including socialscientific ones. While we may be surprised upon hearing news of a civil war or a war between two nation states these events hardly ever cause the shock and horror that comes from terrorist attacks. This is true even if the first set of events causes more harm and destruction than the second (for instance the human toll of the war of Iraq has far exceeded that of the 9-11 attacks, yet it is the latter which still produces fright and confusion).

In this respect, the recourse of some terrorist organizations to what are perceived as "shocking" acts of violence, and the very perception of the acts as disturbing the normal course of events, as opposed to say the way war casualties are perceived, can be explained as a result of this very illegitimacy (Poggi 1990). The reason for this is that warfare as a form of violent interaction in the international system is ritualized and cognitively legitimated (Bornschier and Chase-Dunn 1998; Giddens 1987). This legitimation of warfare is no doubt connected with the legitimacy of the state as the primary actor (and source of agency) in the international system (Meyer, Boli, Thomas, and Ramirez 1997). This is also the reason why state actors respond more swiftly with repression when they perceive an act of insurgency to be "culturally deviant" net of frequency (Davenport 1995). In the case of war, the state actors involved can draw on a virtual armamentarium of centuries-old rules and conventions (Martin 2005). On this shared normative structure, they can regulate their moves and countermoves and justify their actions - using consensually defined "vocabularies of motive" (Mills 1940) - in the eyes of the larger international community. From a world-systems perspective, war, far from being chaotic, is an integral part of the international state system's processes of order maintenance, normative structuration and economic and political selection (Bergesen 1985; Modelski and Thompson 1996). ${ }^{1}$

Terrorists, however, are the international state system's outlaws, incapable of justifying their actions within this nation-centric "Westphalian" system of rules and conventions, and unable to lean on tradition and custom in their attempt to engage in political violence. It is possible therefore, that the apparent "chaotic" nature of terrorist violence may simply be endogenous to the illegitimate status of the activity in the international system, and not inherent to the specific behaviors and strategies that terrorist organizations usually engage in and deploy. It

\footnotetext{
${ }^{1}$ This observation is meant to apply to inter-state war. The phenomenon usually referred to as major power or "general" war (Goldstein 1988; Kennedy 1987), is indeed an indication that the system has entered a state of chaos (Arrighi and Silver 1999), out of which will emerge a renewed global order arrangement (Modelski and Thompson 1996). Whether this form of warfare is itself "functional" is still a contentious issue (see Levy 1985 for a classic statement).
} 
is likely that most of the definitions of terrorism proposed so far flounder due to the fact that without putting forth normative demarcations inherent in the Westphalian institutional system (i.e. differentiating civilian casualties produced by state armies as justifiable "collateral damage" from those produced by non-state agents), there is no qualitative characteristic of terrorist actions that would be sufficient to distinguish terrorism from other types of military or violent interaction or sufficient to distinguish violence-producing organizations that specialize in terrorism from other non-state affiliated violence-producing organizations (e.g., guerrillas). Restricting terrorism to the targeting of civilians and non-combatants for the purposes of political violence (Goodwin 2006), or the usage of violence in order to create an atmosphere of psychological and moral disorganization (Schmid and Jongman 1988), is not sufficient.

This analytic strategy fails for two reasons: first, it is overly exclusivist, leaving out a large part of "routinized" terrorist activity that does not aim to produce extraordinary and shocking events, but which is closer to guerrilla warfare and is still directed at the state and its symbolic representatives. Second, it is overly narrow, in that it does not suffice to make terrorism distinctive from inter-state war at the level of empirical observation and behavioral interaction. After all, the killings of civilians, the targeting of non-strategic symbolic targets (such as famous landmarks), or sustained bombings of cities for demoralization purposes, are all strategies that have been put to use during interstate war, but are not usually branded as terrorist (Graham 2004). Furthermore, terrorist attacks have - admittedly not with the same frequency - been directed at military targets (as in the USS Cole incident).

This situation then leads to the nominalist pessimism that terrorism is what people, authorities and ideologues decide to label as terrorism, without a theoretical defining feature of its own. I argue that, while it is correct to note that there is no set of actions or behavior pattern that is exhibited exclusively by terrorist groups and that would serve as a unique criterion that could be used to distinguish terrorism from other types of violent phenomena produced by different actors in the interstate system, the nominalist conclusion that terrorism has no theoretical substance of its own does not follow (see also Bergesen 2007 for a related but distinct attempt to define terrorism as a sui generis phenomenon). ${ }^{2}$

If particular actions cannot be used as measuring rod to arrive at a definition of terrorism, then where does this leave us? Here I suggest that the unique perspective afforded by a more global viewpoint can be used advantageously to move beyond the limitations generated by looking at terrorism from strictly intra-societal or social-psychological viewpoints (Bergesen and Lizardo 2005). From an international relations perspective for instance, one important component of any violent interaction is the type of actor that performs the deed and the type of actor that is seen as the target (Bergesen and Han 2005).

Given two equivalent actions (such as a surprise attack against a state), one performed by a recognized actor in the international system (such as Japan in during World War II), and another by a loosely defined network of infra-national actors (informal groups, non-stateaffiliated organizations), the first would be characterized as an act of war while the second would

${ }^{2}$ A similar problem plagues definitions that focus on the types of non-state organizations that resort to terrorism (such as the oft noted slogan that terrorism is a "weapon of the weak"). As noted by Goodwin (2006) there are too many empirical counter examples to support any view that restricts terrorism to any particular type (weak, strong, elite, mass, conservative, revolutionary, etc.) of non-state organization. 
most likely be referred to as a terrorist attack. Conversely, a civilian who kills another civilian is a murderer, not a terrorist. But a civilian who kills another civilian and then posts an elaborate rationale on the internet for his actions connecting his victim to a prestigious corporate entity (such as a nation state) would immediately be branded a terrorist. Conversely, if an individual as a representative of a nation state kills a civilian, then we can say that an episode of state terrorism has taken place.

In all of these cases, focusing on the kinds of actors (and the institutionalized rules that constitutively define certain actors as "representative" of certain macro-actors in the interstate system) instead of the kinds of action (which remains constant), allows us to get away from the thorny normative and conceptual issues that come to the fore during any attempt to arrive at a definition of terrorism by focusing on the "terror" part of the output of terrorist organizations. ${ }^{3}$ After that first hurdle is cleared, we will have an operational characterization, one that may be utilized when conducting research without having to worry about subjective and cultural incommensurabilities.

\section{TERRORISM AND THE NATION-STATE: AN ACTOR CENTERED PERSPECTIVE}

\section{The Targets of Terrorist Organizations}

In this section I analyze the long-standing relationship between terrorism and the nation-state (Wilkinson 1977) from the actor-centered viewpoint sketched in the preceding section, while elaborating on the institutional argument that the qualitative "terror-producing" feature of terrorist violence should not count towards its definition.

I begin with the observation that when talking about non-state related episodes of terrorism, the intended target of terrorist attacks is almost invariably a recognized actor in the larger inter-state system or a proxy for such an actor; in what follows I argue that this is the defining feature of terrorism. Not its clandestine or apparently "indiscriminate" quality, since both of these are a necessary by-product of the forced choices foisted upon any non-stateaffiliated organization that aims at the production of violent events under contemporary institutional arrangements (and not a direct goal or ideal choice of means of terrorist organizations). In essence these are the "rational" expediency strategies that Rapoport (1984:674675 ) thinks of as distinctive of modern terrorism. Furthermore, both the relative clandestine status and the relative level of target discrimination vary systematically across different types of terrorist organizations as we will see below.

By the phrase "contemporary institutional arrangements", I mainly refer to the classic Weberian observation (see also Price 1977:55; Tilly 1990:70) of the taken-for-granted monopoly of the state to engage in violent military action (along with the routinized rules and conventions of war developed in the Westphalian system), and the necessary lack of legitimacy of any other

\footnotetext{
${ }^{3}$ Notice that this does not lead us to conclude that terrorism is some sort of platonic, ahistorical category. Since actors themselves are historical constructions subject to time bound material, cultural and institutional elaboration (Thomas and Meyer 1984), what terrorism is and what type of collective violent interactions in general are structural possibilities of the system co-evolves along with the system itself and the types of actors that it produces and destroys (Pollins 1996).
} 
non-state entity that produces violence. As Tosini (2007:665) has recently noted, labeling terrorist activities "unconventional" or "extra-normal," already "implies a specific legal and political position, generally expressed by all states." In this respect, non-state affiliated violenceproducing organizations are tagged as "terrorists," "because of their challenge to the monopoly of (the legitimate use of) political violence held by a state within a territory" (2007:665).

Taking this stance prevents us from getting sidetracked by giving undue focus to the the alleged - and presumably normatively definable - "extranormal" essence of terrorist actions, strategies or exploits throughout history (as does Rapoport 1984:660). Paying attention to institutional rules instead allows for a more analytically advantageous focus on the structural and relational features that all episodes of non-state terrorism in the modern (Westphalian) system have in common: a violent interaction between representatives of a non-state organization and representatives of a nation-state (or other territorial, violence-monopolizing actors). From this viewpoint the study of terrorism begins by answering two questions: (1) where is the violence producing organization situated vis-a-vis other violence-producing actors in the system? And (2) what type of actor is the target of the attack?

Thus, our actor-centered perspective leads us to our first conclusion: in the contemporary Westphalian system, terrorists attack actors linked to territorial states (Pape 2003). Civilian attacks are a by-product of the larger goal of terrorists to attack representatives of nation states; and within the modern citizenship incorporation system (Marshall 1950) - civilian-citizens happen to be the most logistically attractive and tactically available representatives. It is this sense that modern terrorism and relatively historically recent mechanisms of polity incorporation, such as citizenship, have been mutually constitutive throughout history. Thus, if terrorist organizations harm civilians, they harm them in their status as representatives of states, or what Goodwin (2006) refers to as "complicitous civilians." Although I believe that the term "civilian" and the specific requirement that these civilians be seen as receiving some sort of instrumental benefit or "collaborating" with the state in question is too restrictive in this context.

Instead, terrorists attack symbolic representatives of territorial, violence-monopolizing state actors. All that needs to exist is a publicly accepted and institutionally recognized cultural linkage mechanism - such as citizenship - between those representatives and the state-actor in question. This has been the case throughout the history of terrorism, from the Zealot's attacks against the Roman occupying forces in the first century A.D. (Hess 2003; Rapoport 1984) and the Assassins' famous $13^{\text {th }}$ century exploits against high-standing state representatives in the Muslim Caliphate (Rapoport 1984), to Russian anarchist attacks against representatives of the Tsarist regime in the second half of the $19^{\text {th }}$ century (Joll 1979). ${ }^{5}$ Furthermore, it is not a requirement

${ }^{4}$ According to Goodwin (2006:2037), "Revolutionaries view these categories of civilians as complicities insofar as they are believed to (1) routinely benefit from the actions of the government or state that the revolutionaries oppose, (2) support the government or state, and/or (3) have a substantial capacity to influence or to direct the government or state."

${ }^{5}$ Notice that under this definition, even the fact that modern terrorism focuses on representatives of nation-states is not a critical feature of terrorism. Instead, this is simply a by-product of the fact that in the post-Westphalian world-system, states happen to be the most legitimate, obdurate and powerful violence-monopolizing territorial corporate actors around. If world-empires still existed, then terrorists would attack imperial representatives (i.e. as with Zealots and Sicarii). Notice that under conditions of state failure in which other corporate agents come to acquire more 
under this characterization that the representatives that are the target of attacks be natural persons. Objects (monuments, buildings, etc.) can also play that role (Gibbs 1989:331). Furthermore, the more prestigious and the more symbolically associated with the territorial actor in question (i.e. the White House vis-a-vis the United States) the more likely it is to be desirable as a terrorist target. This explains why targeting the head of state directly (i.e. Leon Czolgosz's shooting of U.S. President William McKinley on September 6, 1901 in Buffalo, NY or the Naradnoya Volya's successful attempt on the life of Tsar Alexander II on the first of March of 1881) - as the ultimate representative of the modern nation-state - has always been the holy grail of terrorist organizations since the emergence of modern terrorism in the second half of the nineteenth century.

\section{Categorical Terrorism}

Terrorists usually take civilians and public figures as standing for the states that they wish to target. Why do they do this? As noted above, the peculiar status of terrorists as illegitimate violence-producing actors in the international system can be used to account for this phenomenon. ${ }^{6}$ First, while national armies engaged in war do not have to solve the problem of identifying each other as mutual targets (given the availability of true and tried conventions such as different uniforms). Terrorist actors suffer the problem of being unlawful initiators of a military interaction against representatives of a nation-state and have therefore, throughout history resorted to a generalizing strategy (Rapoport 1988): everybody that is, by virtue of some citizenship or other symbolic mechanism, associated with the corporate (usually a state) actor that they wish to target becomes a representative of that actor and therefore a potential target for attack.

Thus, the civilian-combatant boundary becomes blurred not because of some mysterious "barbaric" or "indiscriminately violent" predisposition among actors branded as terrorist, but due to the very illegitimate position that they occupy in the interstate system. From this point of view, the indiscriminant modus operandi of most terrorist organizations is simply a forced-choice produced by their very peripheral position among the entities endowed with the legitimate capacity to engage in violence (i.e. national armies, national police forces, secret commandos, etc.). Here is a case when positioning terrorist organizations in the context of other violenceproducing entities in the interstate system and focusing on violent interaction and warfare as a historical institution (Giddens 1987), can help us explain an apparently puzzling facet of their behavior pattern.

This last statement also has an important empirical implication, which is that as terrorist organizations become more legitimate actors in a particular struggle, indiscriminate attacks

legitimacy than the state (i.e. legal corporations, drug cartels or other collectively organized criminal actors) then terrorism may be directed at its representatives. This explains why terrorists who were ideologically motivated by Marxist political theory (i.e. the various European "Red Armies" and the German Baeder Meinhoff "gang" of the 1960s and 1970s) which points to the ultimate controlling role of private, capital-accumulating actors and not territorial state actors as the primary agents in the world system, sometimes targeted corporate symbols and human representatives of transnational corporations rather than states.

${ }^{6}$ Terrorist organizations may of course enjoy local legitimacy in certain circumscribed settings. 
decrease and more targeted operations increase. This connection between organizational legitimacy and discriminate selection of targets of violent interaction also explains why state terrorism is seldom indiscriminate, but on the contrary, it is usually highly targeted and discriminate (Price 1977:53), with specific "lists" of potential political enemies carefully prepared before-hand by state agents as in the Argentinean transitional military regime of the 1970s (PionBerlin and Lopez 1991).

The state in contrast to non-state-affiliated (or supported) terrorist organizations is usually a highly legitimate entity in the current state-centric world-system and therefore can afford to be discriminate. We can explain the indiscriminate "total terror" of the French state during the immediate post-revolutionary period of 1789 or the indiscriminate counter-terror of the Batista regime in Cuba in the late 1950s (Price 1977:54) by the fact that the revolutionary state in France and the U.S. supported Batista regime in Cuba both exhibited extremely low levels of legitimacy. If this hypothesis is correct, we should also expect that indiscriminate acts of terrorism on the part of state agents should increase as state legitimacy and structural strength decreases or is seriously put into question by a strong domestic challenger (Mason and Krane [1989] provide support for this hypothesis). ${ }^{7}$

This is also the reason why colonial states (whether "internal" colonialists or traditional metropolis-satellite systems), which tend to be more illegitimate-such as the French in Algeria - tend to be (ceteris paribus) more indiscriminate than local state actors when resorting to terrorism. In the very same way, non-state actors who are oriented toward the dominant, legitimacy-conferring institutions of the international system seldom engage in terrorism. This was the case of the South African ANC, who went as a far as to sign the engagement protocols of the Geneva convention (Goodwin 2007 ).

The "new" religious terrorism (Juergensmeyer 2001; Stern 1999) has been characterized precisely because of its "indiscriminateness", reviving older theories about the dispositional blood lust of terrorists. However, from our legitimacy perspective, indiscriminateness on the part of organizations that have a religious identity is to be expected, since in the current global context of the dominance of Western, secular models of political and social organization, terrorist religious organizations have a double legitimacy handicap, as both terrorist and religious. If an initially religious organization is over time transformed into a more conventional political terrorist organization, we should expect its indiscriminateness to decrease.

This would explain why for instance Hamas (a quasi-religious organization) tends to be more indiscriminate in its attacks than Fatah (a product of the 1960s Arab secular Left) and why the paramilitary wing of the IRA has been much more indiscriminate than the Basque ETA (de la Calle and Sánchez-Cuenca 2006, table 1). In a pre-modern context, of course, there should be no correlation between target discrimination and the status of an organization as both terrorist and religious. The Assasins for instance, had the ability to orchestrate highly targeted killings throughout their long history (Rapoport 1984, 1988).

Second, as noted above, terrorists face a double cognitive (and "sense-making" [Weick 1995]) problematic as organizations that is not experienced by members of national armies: one

${ }^{7}$ This is also one way to put empirical content on Gianfranco Sanguinetti's otherwise purely rhetorical thesis that "All States have always been terrorist but they have been so most violently at their birth and at the imminence of their death" (Sanguinetti 1982:99), since these are the two periods in which state actors are expected to reach their lowest point in terms of legitimacy. 


\section{JOURNAL OF WORLD-SYSTEMS RESEARCH}

is related to the agreed upon conventions (Lewis 1969) that convey information as to the type of actors involved in the situation, and the other stems from the legitimacy gained by a recognized association with a national entity. The first I will call the informational problem (who is a proper representative of the target I wish to attack?). The second is a different variant of the legitimacy problem, and this is tied to the reluctance of the larger international order to recognize some entities (nation states) and not others (non-state organizations) as proper wielders and monopolizers of the means of collective violence (not surprising, given that the dominant actors in the international system are nation states).

In terms of the informational problem, terrorists are not afforded the set of conventions that are granted to legitimate combatants. Soldiers - when not involved in irregular activities such as urban warfare-know beyond a shadow of a doubt which personal agents are to be considered representatives of the enemy. That is why soldiers who attack civilians are considered war criminals by international law; the very act of attacking civilians is not considered an involuntary error but a deliberate act of murder. The reason for this is fairly obvious. Given the existence of internationally shared social conventions it would be impossible for a soldier to kill a civilian without realizing it (unless he or she is mentally incapacitated in some way).

Terrorists, given the lack of a base of social norms for delineating the guidelines for the activity that they engage in, must consider every person that by virtue of geography, language or culture (a much "fuzzier" set of criteria) gains an association with the enemy state a representative of that enemy state. Soldiers who belong to national armies do not have to face that quandary as they are aware of their legitimate status as proper bearers of their own nation state's capabilities and monopoly over the means of violence. International actors who are branded as terrorists, however, are groups who are not recognized as official entities in the international system (akin to pirates and smugglers in the world economy), and who therefore cannot have access to the set of conventions reserved for "rightful" representatives of nation state.

This indiscriminate "nature" of terrorism is the "categorical" feature that has been noted by many commentators (Black 2004; Goodwin 2006). However, from an actor-centered perspective, this feature of terrorism is best seen as deriving from the position of terrorist organizations in the contemporary international context - and thus as a temporal and spatial variable not a constant (de la Calle and Sanchez-Cuenca 2006) - and under the contemporary rules of organization for the production of collective violence, rather than an essential defining feature of terrorist activity. ${ }^{8}$

It is important to clearly appreciate why the above considerations also disqualify the killing of civilians (or other noncombatants for that matter) as the defining feature of terrorism. Incidents such as Al Qaeda's October 12, 2000, attack on the USS Cole demonstrate that

\footnotetext{
${ }^{8}$ Goodwin (2006) differentiates categorical terrorism from terrorism directed at individuals qua individuals - what he terms "targeted assassination." However, it is doubtful that we can find episodes of terrorism proper in which the victims are selected purely in terms of their individual identity some form of corporate identity is always attached to the individual even if this identity is not purely national(member of a police force, executive of a corporation, etc.) - this itself is a historical variable connected to the rise of prominence of the nation-state as the dominant actor in the modern system (Meyer et al. 1997). Purely individual terrorism, collapses into murder, and other types of group violence, such as lynchings (Senechal de la Roche 1996) or "mob" violence used by protection rackets to enforce their dominance in circumscribed geographical areas.
} 
terrorists may target non-civilians. And without denying the obvious pragmatic reasons as to why the majority of terrorist attacks do occur with civilians as the primary target (publicity, feasibility, the relative vulnerability of the civilian population), it is useful to realize that beyond the civilian/soldier, combatant/non-combatant demarcation, the criterion of representation (is the target associated with the nation state that I wish to target?) is the primary decisive factor in the selection of a particular target (whether human or infra-structural). ${ }^{9}$ The second important thing concerns how the state-actor that is attacked "defines the situation."

In the current system, being a member of state army or a recognizable citizen of a nation state are fairly strong linkage mechanisms. But these are specific to the present historical setting, and clearly not the only possible ones. This means that a definition of terrorism should be neutral as to the specific institutionally defined practice of "symbolic linkage" that terrorist actors use to connect persons to the corporate actors they wish to target (although in the present setting, citizenship is a pretty safe bet). For instance, it is clear that the Israeli athletes killed in the 1972 Munich Olympics by the Black September organization were not attacked in their public roles as athletes, but in their role as representatives of the Israeli state in the global arena. Thus, this attack was tantamount to a politico-military violent interaction between the terrorist organization and the Israeli state (the subsequent covert manhunt of those thought responsible for the killings by Mossad agents can be seen as the obverse of the initial interaction).

It is clear that most episodes of terrorism-counter-terrorism cycles are indistinguishable at a behavioral level from what has been referred to as "total war" (O'Sullivan 1986:16) when this occurs between two formally recognized state-actors. The only difference is that the non-state actor in the interaction is usually not formally recognized as a valid "partner" in the military interaction by the state-actor (i.e. in the state-centric international system only representatives of other state actors count), and therefore the situation cannot be institutionally defined as "warfare" (note that the Bush administration declared a war on "terror" but not on al Qaeda). Therefore, any attack by a non-military, non-state affiliated organization upon representatives of a nation state qualifies as "terror." Analytically, there is no reason why this same criterion should not apply. One thing to keep in mind is that this process of definition of what is happening in the situation is dynamic and to a certain extent, self-fulfilling: if the non-state actor gains enough strength to be able to confront the state's military forces on its own terms (i.e. following the conventionally established rules of warfare), then the situation moves from one featuring terrorism to one that can safely be defined as a "civil war."

In the case of contemporary sub-state terrorism, therefore, we can arrive at a minimal definition: Modern terrorism refers to a type of violent interaction initiated by a non-state actor, which is not formally recognized as a legitimate wielder of the means of violence or a valid initiator of violent interactions, directed against the representatives (human, material or symbolic) of a formally recognized state actor in the international system, which does not follow the institutionalized rules and conventions of military engagement.

\footnotetext{
${ }^{9}$ As Goodwin (2006) notes, citizenship is not the only representation mechanism, and different groups will cut the "representational pie" in different ways, with some groups taking all members of the nation state they wish to target as potential victims (more likely to occur in democracies), and with others using an overlapping set of criteria in which citizenship is necessary but not sufficient (i.e. a revolutionary leftist group who attacks only those who are American and businessmen).
} 
The division between "domestic" and "international" terrorism corresponds to the special cases in which the members of the organization attack representatives of a state with which they share a territorial and political affiliation or attack representatives of foreign states (Enders and Sandler 2002). The above definition also points to the need to differentiate terrorism as a tactic (which may be used by military organizations such as state-affiliated armies or formally organized guerrillas) from terrorism as a generic violent interaction between non-military organizations and state representatives. As it stands, this definition is still incomplete (or rather it remains at too specific a level): it leaves out terrorist activity that is not directed at formally recognized territorial actors (nation states), but at private corporate actors such as major corporations (i.e. an animal rights group burns a McDonald's) or at coalitions of nation-states (incipient Intergovernmental Organizations). However, notice that the problems with the definition are not insurmountable from the present perspective, since they point to other types of actors that may be the target of terrorist organizations and such objections should thus be amenable to conceptualization within an actor-centered approach. But first, it is important to elaborate on the full implications of this actor-centric perspective for organizing the "forms of violence" that can be observed in a given world-system at a particular point in history.

\section{A TYPOLOGY OF INTERSTATE SYSTEM VIOLENCE}

The conceptual and definitional problems posed by the question of terrorism in the international state system can be used as a springboard to address other conceptual difficulties in the treatment and theoretical status of war and international conflict in current debates in the international relations literature. The world-systems approach lead to a re-conceptualization of international conflict as a constant and recurring feature of the interstate system (Bornschier and Chase-Dunn 1998), rather than as a random or historically contingent occurrence. This represented a tremendous advance over previous social scientific views of the phenomenon as simply chaotic and unexplainable or inherently tied to exclusive intra-societal dynamics. Nevertheless, serious conceptual problems remain. Most of these problems can be traced to a set of analytic assumptions regarding the nature of the entities that are postulated to interact in the interstate system and the theoretical framework that is usually resorted to in order to explain their behavior.

\section{Interstate System Actors and Violent Interactions}

In the international relations and world systems literature, military interaction is considered to be one type of linkage between the elements of the world system (Chase-Dunn and Hall 1997), with economic, cultural and political interactions comprising the other major types of contact, it is always assumed that these interactions occur between nation-states or other established macropolitical entities such as empires and city-states (this is in spite of the fact that one of the most important of recurrent military interactions in the history of the Eurasian system came from a non-state entity: the Mongols). ${ }^{10}$

${ }^{10}$ The fixation with the nation-rather than the "entire system" as first proposed by Wallerstein (1983) - as the exemplary acting unit in world system theory has recently been challenged due to the emergence of forms of economic and political interaction that transcend national boundaries 
As Vinci (2008) has recently highlighted, this theoretical blind-spot has been built-in to the neo-realist perspective since its inception due to its implicit allegiance to the Hobessian dichotomy between state-based "order" and state-less "anarchy." However, it has become increasingly clear that states are not the only actors in the international system capable of producing local (and regional) forms of order, nor are they the only actors capable of interacting with one another in an organized fashion (and thus forming "systems" or being embedded into larger state-dominated systems [Mann 1986]). Accordingly, taking into account recent structural re-organizations in the interstate system, and re-framing the nation state as a meso-level of analysis (nested within an already macro level of analysis), it becomes clear that interstate war is one of a number of possible military interactions between different types of actors in the interstate system. Using a crude form of classification, we can therefore distinguish between national actors, infra-national actors and supra-national actors.

Within this framework, military conflict can occur either between two nations (what has traditionally been referred to as interstate war), between a supra-national entity (such as NATO) and a particular nation state (e.g., Serbia), or between an infra-national entity (Al Qaeda) and a nation state (The United States). There are two other possibilities of course: a military conflict between two infra-national entities (i.e. organized ethnic violence), or two supra-national entities. The former, given that they occur within the boundaries of specific nation states, pose no conceptual difficulties and have been the province of standard studies in the sociology of revolutions and social movements (there is a now growing literature in Political Science and Peace Studies designed to explain the origins of civil war). The latter however, comprise what has been referred to in the literature (Gilpin 1981; Goldstein 1988; Levy 1985; Modelski and Thompson 1996) as general wars (such as the 30 year war of 1914-1945), where a major conflict occurs between two mutually opposed interstate alliances or coalitions (which can be considered a temporary intergovernmental organization), and thus represents an example of conflict between two supra-national entities. This is consistent with Chase-Dunn and Sokolovsky's (1983:366), definition of a "world war" as "those military engagements that involve rival coalitions of state forces where at least one core power is a member of each of the opposing alliances (italics added)."

Regional and major power wars are sometimes treated as simply a subset of the category of nation-to-nation war (or vice versa). However, the point that is usually missed by this analytic decision is that these wars do not occur between isolated nation states, but between allied groups of nation states or formal supranational organizations composed of a league of nation states, and therefore represent a distinct type of phenomenon. This is because-following an old Durkheimian truism of the emergence of collective actors out of individual actors-major power warfare engages a distinct type of actor distinguishable from the nation state, and is thus empirically and analytically distinct from interstate warfare. ${ }^{11}$ Figure 1 shows how various forms

(i.e. NGO's and TNC's) either from the supra-national (Robinson 2001) or the infra-national side, as in the new preoccupation with the global-local nexus. While recent developments in world system theory have moved to accommodate these newly prevalent phenomena, the analysis of military interaction has remained tied to the level of the nation-state.

${ }^{11}$ The first such supra-national actor in the history of the European interstate system is widely recognized to have been "The League of Venice" formed during the first Italian War of 14941498. 
of collective violence in the international arena can be organized within this structural framework of types of actor (organized by their "scale") from non-state organizations - the most minimal of which is the lone perpetrator-to supranational coalitions of states.

Figure 1: Forms of Violent Interaction by Type of Actor in the Interstate System

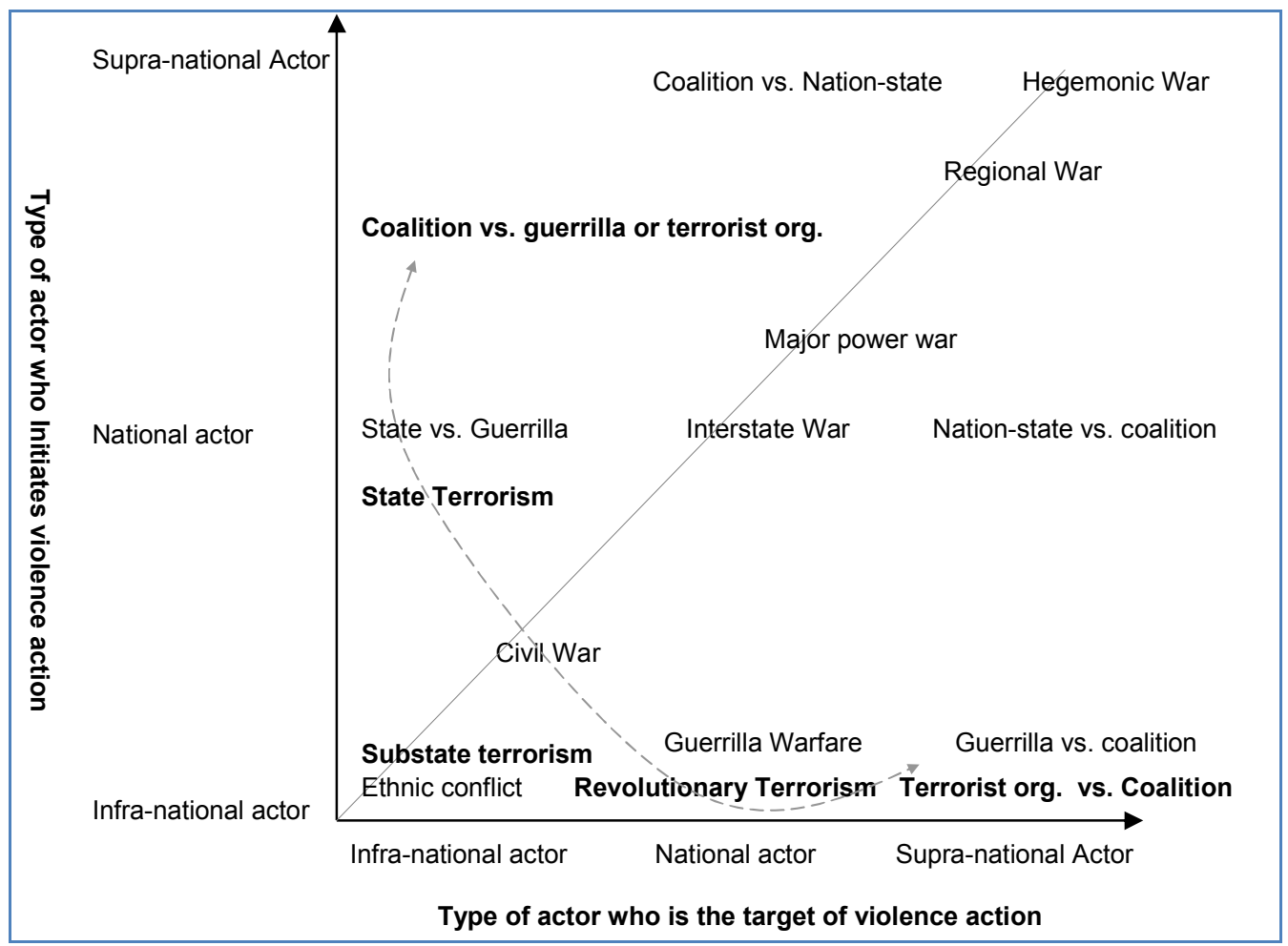

Notice that the phenomena located along the main diagonal of the figure are the "official" subjects of studies in Sociology and Political Science (evincing the propensity of researchers to remain focused on cross-actor interaction at the same level of analysis). Long and well established literatures exist on the subject of religious and ethnic conflict, civil war, interstatewar, regional war and major power warfare and even interactions that have all of the characteristics of terrorism (i.e. being illegitimate, illegal, etc.) but which happen to occur between two different non-state actors in a given territory (Vinci 2008). There is a good reason for this, since these types of violent interactions are also the most historically common occurrences, and thus examples extend far and wide both geographically and chronologically enabling the construction of data sets that can be subjected to rigorous empirical analysis (e.g. Hironaka 2005) or to detailed comparative analysis across different historical periods.

Of particular interest in the present context, since that is where most of the violent interaction usually referred to as terrorism lies - are those phenomena located "off the diagonal" of this figure. These represent events that cross levels and that due to the specific re-organization 
of the interstate system in the present transition period (with the more active role played by supranational entities and the proliferation of non-state affiliated actors) represent increasingly likely structural possibilities (although they have occurred recurrently throughout the entire history of the Westphalian system). Thus, military action initiated by infra-national or national actors against a supra-national entity (lower and middle right-hand side of the figure), ${ }^{12}$ and violence initiated by supra-national actors or national actors and directed at a non-state actor (upper left hand of the figure) may become common future occurrences. ${ }^{13}$ A cold-war example of this type of phenomenon consists of Operation Condor in which a coalition-and thus a supra-national actor - of right-wing governments from the Southern Cone of South America engaged in a concerted campaign of military repression against various left-wing nonstate actors - mostly revolutionary guerrilla groups - throughout the entire region. Finally, in the upper-middle region of the figure we can find the case of a supra-national entity engaging in violent interaction with a national actor. ${ }^{14}$

It is important to retain the analytic distinction between phenomena located in the lower left hand side of the figure (civil wars, revolutions, religious and ethnic violence) and those in the lower-middle region, labeled as terrorism, since there is a long-standing tendency to attempt to reduce the latter to the former. Many revolutions and civil wars begin under the guise of a stateterrorism/domestic terrorism cycle of violent interaction (Alimi 2006; Lichbach, Davenport, and Armstrong 2004) and I argue that they should retain that denomination as long the target nationstate retains its integrity and coherence as a state actor. A national revolution or civil war can only be said to occur when a particular nation state, after a prolonged period of oppositional terrorist and/or guerrilla warfare challenge, devolves into an infra-national actor located at the same level as the challengers (a case of state "collapse", "state fragmentation" or "state failure"). Therefore, civil wars should be thought of as infra-national contests occurring in a common geographic location between two non-state actors (or actors located at a level "below" that of a full-fledged state actor [Vinci 2008]). If the challenger wins the contest, a new national actor can be said to come on the scene, while if the challenger loses and is incorporated, the old national actor re-emerges. If a split occurs, then two new national actors enter the international arena. It is important to note that "terrorism" as here defined cannot occur unless there is a formally recognized state actor is a part of the focal conflict.

Keeping our attention focused on the types of actors allows us to realize that the type of conflict that we may observe can change over time as new actors enter or leave the scene (or are "promoted" and "demoted" into different types of actors), going back and forth from its original denomination - say a civil war-to others and back again. This is a common insight in the analysis of interstate war-where a traditional interstate war between two states can be transformed into a world war or regional war with the entrance of other states into the conflictbut seldom applied beyond this realm of activity.

${ }^{12}$ The case of Somali guerrillas attacking NATO troops would be a close empirical instance of this type of phenomenon.

${ }^{13}$ A United Nations special task force or a coalition of States attacking representatives of terrorist organizations or subnational groups of "nations without states" (such as tribal collectives in Afghanistan) represent an example of this.

${ }^{14}$ It can be argued that the NATO bombings in Serbia are an example of conflict phenomena that fit in here. 
The type of interaction that I want to focus on here is that between an infra-national actor and a national actor proper (lower middle region). This is what I propose should be referred to as terrorism. ${ }^{15}$ Of course, terrorism can take both domestic and international forms, but in both of these cases the analytical commonality remains and only the national actor that is targeted changes: in domestic terrorism non-state groups target a national actor (or its symbolic human and material representatives) that encompasses them both politically and geographically, while international terrorists aim their attacks at symbolic or humans representatives of a foreign national entity (but which may occur in a foreign location, such as an embassy located in the terrorist own "home base" [Bergesen and Han 2005]). Given the above, the blindness of previous sociological theory to phenomena such as terrorism, cannot be justified by pointing to empirical factors (terrorism under this definition has occurred regularly throughout the history of the interstate system) but must be admitted to be conceptual, generated by the difficulty of theorizing violent interactions between entities that go beyond (or below) the scale of nation states.

In addition, this actor-centered typology does not require that we draw a clear line of demarcation between the different types of terrorism. One advantage of focusing of actors is that we can arrange the various forms of conflict that incorporate terrorist actors and appreciate the continuity across different types of violent interaction. As shown by the dotted curved line in the figure, terrorism can encompass everything from coalition troops attacking civilian combatants, to traditional terrorism against local civilians enacted by state authorities, to attacks on the state by terrorist organizations, to attacks on IGO representatives or national coalition representatives by a non-state organization. In this way, our previous anomalous example, that of a terrorist organization attacking a McDonald's establishment can be conceptualized as simply another structural variant of the scheme shown in Figure 1: that of a non-state organization attacking a supra-national actor. This is so since a particular McDonald's establishment is best conceptualized as a representative of the transnational corporation (TNC) that bears its name, and thus the event should be located toward the lower right-hand side of the figure.

\section{TERRORISM AND GLOBAL THEORIES OF THE INTERNATIONAL SYSTEM}

The above considerations directly touch the theoretical issue of the genesis of conflict in the interstate system. It is important to note that most international conflict theory has been designed to explain conflict among nation states, while most social movement theory in sociology and political science is designed to explain (non-military) conflict between the state and challenger groups, or between two or more substate factions (ethno-religious violence). Still various studies have proposed that all of these phenomena mentioned above, from wars (Bornschier and ChaseDunn 1998), to state-repression and revolutionary movements (Boswell and Chase-Dunn 2000) and intrastate conflict and civil war (Hironaka 2005; Olzak 2006) are embedded in and are directly affected by global rhythms and processes and as such, theories of conflict developed in the international and world systems literature offer useful explanatory vantage points. It is therefore unclear, why terrorism - both state and non-state - should be left out of this list

${ }^{15}$ This classification also has the advantage of disentangling state terrorism from terrorism proper. While state terrorism is simply the converse of terrorism (a state attacks and infranational actor) its dynamics and correlates maybe of a different sort than terrorism. 
(Bergesen and Lizardo 2005). In this section I sketch some of the global processes most likely to be connected to non-state terrorist activity. I limit my discussion to the possible impact of the following global factors: long-term economic cycles, global political and normative factors, phases of system structure (unipolar, bipolar, hegemonic, multicentric, etc.) and global cultural factors.

\section{Terrorism and Global Long-term Economic Cycles}

World-economic cycles and trends have always figured in World-systems and international relations explanations of interstate conflict and intrastate violence such as state-led repression and civil war (Bornschier and Chase-Dunn 1998; Boswell and Chase-Dunn 2000). To explain interstate conflict, some argue for the primacy of economic factors ("the resource view") while others point at the political structure of the international system, with a unicentric arrangement reducing conflict and a multicentric structure inducing it (Arrighi and Silver 1999). ${ }^{16}$ Political scientist Brian Pollins (1996) has argued that the general strategies that most researchers utilize in order to deal with this theoretical issue can be classified into three different types: conflation, reduction or co-evolution. Those who conflate economic and political (global order) processes simply do not make any distinction between economic and political systemic properties, or view them as perfectly reducible to one another. A second group tries to reduce one to the other arguing that either economic or political processes are determining in the final instance. The third group takes a more integrative stance admitting that the two processes, while analytically and empirically autonomous, have a certain degree of interconnection.

In the explanation of terrorism, most analysts who pay serious attention to global economic and/or political factors follow a similar tack: reductionist economic theses, in which terrorism is seen as a byproduct of economic exploitation along the North/South, Core/Periphery axis abound, although empirical support for most of their contentions is ambiguous at best ( $\mathrm{Li}$ and Schaub 2004; Lizardo 2006). One problem with purely economistic theories is that world economic flows and exchanges are usually conceptualized solely as the root motive of terrorist activity (from the exploitation model), but seldom seen as an actual facilitator of terrorist action (by way of resource provision as in interstate warfare theories).

Purely political theories - e.g., terrorism as "blowback" from major power imperial games and interventions (Johnson 2003) - err in a similar way, by downplaying cultural and normative factors and ignoring global linkages beyond the satellite-metropolis political domination connection. Instead of engaging in one-sided attempts to explain terrorism as resulting from the simple effect of a single global force, I suggest that it is more helpful to look at the co-evolution of political, cultural and economic processes and particular configurations of global system parameters that help facilitate (or curb) terrorist activity, both domestically and internationally.

If we are to take seriously the suggestion that terrorism is but one more species of violent interaction in the global system, we should attempt to seriously explore whether extant theories designed to explain violent interaction among nation-states in the international system can be

\footnotetext{
${ }^{16}$ This argument can take mirror image opposite forms, as some maintain that war is more likely to occur during the upswing of an economic wave (Goldstein 1988) or as result of the setting in of a downturn (Bergesen 1985).
} 
applied to the explanation and prediction (or retrodiction) of terrorist activity. Where extant theory does not appear to handle the case of cross-level interactions such as terrorism particularly well we can take the opportunity to suggest some recommendations and extensions.

\section{Terrorism and the Resource View of International Conflict}

The phenomenon of terrorist political violence and terrorist organizations as ambiguously recognized actors in the transnational arena makes problematic the distinction between economic and political factors in international relations theory. Resource views of the connection between long waves and violent conflict implicitly conceptualize nation states as rational actors. Those who argue that warfare is more likely to occur during economic upswings - the "war chest" hypothesis - assume that nations always want to go to war and that it is more convenient to do so when resources are abundant (as war is resource intensive). Those who argue that nations go to war during downswings, assume that they do so as a way to jumpstart their stagnant economies through the large-scale mobilization that usually accompanies interstate warfare.

But for infra-national interstate actors economic considerations (at least in the sense of an economic system organized under national auspices) are not of primary relevance. While they obviously require resources if they are to engage in military action (especially against more powerful national targets), the availability of those resources can be independent of the fate of the formal world economy as they can be amassed through informal (underground) economic channels. Thus, the sole focus of international relations research on the legitimate economy, ignoring the possible influence of the black market as a resource base for outlaw groups, becomes a problematic theoretical and empirical issue. If black market activity tends to become more prevalent under certain interstate system power configurations (i.e. multicentric or periods of "hegemonic decline"), then this could be a possible route of explanation for the noted association between waves of transnational terrorism and hegemonic decline (Bergesen and Lizardo 2005).

\section{Terrorism and Normative-Political Order Perspectives}

When it comes to the systemic factors affecting the occurrence of terrorist phenomena, it should be expected that normative considerations related to issues of global order and system governance (Arrighi and Silver 1999; Modelsky and Thompson 1996) should be of primary importance. It is important not to lose sight of the fact that terrorism as a special form of systemic unrest is inherently connected to the dynamics the larger systemic properties of capitalism as a global mode of production (Chase-Dunn 1998). However, the more proximate causal factors may be tied to those related to political order issues connected to the breakdown of the normative consensus under conditions of system strain and the transition from a unicentric (hegemonic) phase to a multicentric international arrangement (Bergesen and Lizardo 2005).

Among the factors that are to be considered the primary constituents of this global order are the rules of diplomacy and military engagement that are espoused as necessary for the maintenance of interstate system coherence. Terrorists violate these rules both by breaking the implicit compact that determines what types of entities are to be considered legitimate monopolizers of the means of violence in the interstate system (both within and between political borders) and by directing their attacks at actors (nation-states) who are already recognized as proper members of the existing system. 


\section{Terrorism and Hegemonic Transition Perspectives}

However, in the international system norms do not exist in a vacuum. In the absence of systemwide order produced by a supra-state, global norms of conduct necessitate their continuing and active espousal by self-appointed system leaders - usually the era's dominant economic and political power - who use their influence to steer the system along their preferred direction (e.g., espousing the global propriety of the values and practices related to democracy and free trade). As noted in hegemonic transition theories in both sociology and political science (Chase-Dunn 1998; Modelski and Thompson 1996), leading powers ("hegemons") experience cycles of ascent, maturity and decline (Boswell and Sweat 1993). Most hegemonic transition theory consists of predictions connecting various global rhythms and trends (i.e. world economic growth, innovation, global war, etc.) with specific phases of the hegemonic sequence of ascent, maturity, decline and succession (Goldstein 1988). In regards to the study of terrorism; therefore, a key question is whether terrorism is more or less likely to occur during different phases of this cycle. I propose that there is a connection: terrorism is more likely to occur during periods of hegemonic decline. There are several reasons for this.

First, insofar as the capacity of the system leader to protect the integrity of the larger normative structure is affected by its position within the hegemonic sequence, and if terrorist activity is aided by breakdowns in the system's normative and political order structure, then some forms of terrorism may be more likely when the system is undergoing transition or the system leader in a state of decline. Second, because the composition and connectivity (or "network") structure of the system are transformed (e.g., during decolonization periods in which a new population of state actors enters the scene producing various new possibilities for possible violent interaction across these entities) as the leading power experiences transitions along these phases, the types of action and the types actors that may garner legitimacy to engage in violent action in the interstate system may not be the same in periods where an undisputed system leader is able to control the system than in periods where multiple sources of control are vying for authority.

What sorts of mechanisms might be responsible for the hypothesized connection between the dynamics of hegemonic decline and the emergence of terrorist phenomena? We know that hegemonic decline is associated with both the proliferation of particularisms and subjectivities and the breakdown of universal conceptual systems (Bergesen 2000; Friedman 1994). Further, periods of transition are characterized by a breakdown of the previous political order secured through hegemonic equilibrium and balance of power (Arrighi and Silver 1999). Among the processes that conspire to destroy the interstate order balance espoused by the hegemon, the most important is the expansion of the region of order that is bequeathed to the hegemon at the beginning of a cycle. Expansion - and the strains that it bestows - is of course a direct consequence of hegemonic dominance, but ironically it is also the cause of decline and subsequent succession (Kennedy 1987).

According to Arrighi and Silver (1999) with expansion, both the volume (the sheer number of actors who are able to join the international arena after adopting the requisite framework) and density (interaction ties within the periphery and between the core and the periphery increase as a result of the increase in volume within the system) of the interstate system increase. This qualitative change at the level of system processes creates strains in the extant hegemonic organizational scaffolding, eventually proving too much for the system to manage, as 
new "interstitial" organizational forms are produced outside of the hegemon's declining sphere of control. The fact that terrorist organizations appeared to have proliferated after the end of the cold war is consistent with this view (Hoffman 1992). Terrorist organizations can be thought of as an example of a new organizational form, what some have referred to in the contemporary period as a "network organization" (Hoffman 2002), as they are loosely bounded and demographically fluid sub-national entities that are characteristic due to their specialization in political violence, and their unabashed attempt to destroy the nation-state's monopolization of this resource in the international system.

We can thus expect the overall volume of entities of all the different types identified above - sub-national, national and supra-national - to increase during periods of transition: Supra-national entities proliferate as core states band together in an attempt to protect themselves from economic competition and upstart politico-military challenges from other core and semiperipheral actors; the number of national entities expands as bouts of nationalism splinter old multi-ethnic states previously supported by the declining core states (i.e. Yugolasvia, the Ottoman empire) and older imperial peripheries decolonize (Bergesen and Schoenberg 1980); and finally, infranational actors multiply as subjectivities and proto-nationalisms spread in the more disadvantaged areas of the periphery and semi-periphery (Friedman 1994). ${ }^{17}$ In the modern period, it is important to add the diffusion and legitimation of the very template of non-state organization itself (Boli and Thomas 1999), which has resulted in the production and gradual progression toward a taken-for-granted status of various international non-state actors chartered with the most diffuse and generalized goals (Meyer et al. 1997).

\section{CONCLUSION: CROSS-LEVEL VIOLENT INTERACTIONS AND HEGEMONIC DECLINE}

The sheer proliferation of all types of actors - sub-national, national and supra-national (i.e. increases in overall organizational density [Hannan and Freeman 1986]) - in the interstate system, coupled with global normative crisis (the delegitimation of the declining hegemonic state [Arrighi and Silver 1999]), should increase the probability of cross-level conflict interaction among actors (off diagonal cells in the figure) during periods of hegemonic transition and succession. At the global-cultural level, non-state actors are empowered and emboldened by the relative gain in legitimacy in relation to both national and supranational collective actors (Boli and Thomas 1999), which opens up both political and cultural opportunity-structures that facilitates the activity of non-state organizations (Lizardo 2006).

In addition, terrorist organizations transpose and adapt extant organizational models (Clemens 1996) from both the non-profit and for-profit sectors (Hoffman 2002), facilitating their survival and adaptability. For their part, the new supranational military organizations turn against "rogue" or otherwise non-compliant nation states, especially those who dare to organize in ways that threaten the established principles of legitimacy (e.g., theocracies, or regimes founded on ethno-nationalist exclusion), increasing the chances of supranational coalitions of major powers engaging in violent interaction against nation states with weaker militaries. In this respect, the

${ }^{17}$ Of course all three of these tendencies are also facilitated by the B-phase downturn in the world economy that characterizes transition periods. 
globalization of resources, techniques and organizational forms makes the struggle between state and non-state organizations much less symmetrical (Naim 2003) increasing both the potential geographical regions that may serve as a haven for non-state organizations, and the chances that an actual state apparatus might fall at the hands of one of these organizations. As Cronin (Cronin 2003:30) points out "The current wave of international terrorism, characterized by unpredictable and unprecedented threats from nonstate actors, not only is a reaction to globalization but is facilitated by it."

Furthermore, the proliferation or "weak" or partially degenerate "quasi-states" in the system's periphery - as a consequence of the partial diffusion of the nation-state form, latedecolonization and empire-splintering processes - increases the chances of state terrorism directed at civilians and other non-combatants on the part of illegitimate state actors struggling to sustain their integrity (Mason and Krane 1989). This dynamic in its turn heightens the chances of civilian proto-military organization against abusive state entities. This results in increasing violent interactions between states and non-state affiliated violence producing organizations in the periphery (what Alimi [2006: 273] has referred to as "interactive contention"). This may result in "spillover" effects as some terrorist organizations flee from particularly vicious stateterrorist machines and direct their attention to safer targets, such as the core state to which their local state is a client or other neighboring states known to support it, resulting in a reluctant transnationalization of terrorism.

While all phenomena along the diagonal (save for major power wars) can occur during hegemonic periods, without violating the integrity of the interstate system (as the hegemon lays out implicit rules that aim at regulating them), cross level conflicts directly contravene standard interstate system rules and their occurrence is a sure sign that the system has entered a state of transition and/or crisis. Chase-Dunn's (1998) world system constants-cycles-trends framework can be a useful organizing device in our consideration of terrorism. It is well known that violent conflict of all types is a constant feature of the interstate system; and research shows that both conflict severity and incidence present cyclical patterns (Goldstein 1988; Pollins 1996). Further, we know that rising conflict severity represents a real trend in the interstate system (Boswell and Sweat 1993; Chase-Dunn 1998).

Is it possible to fit terrorism, as a particular form of cross-level conflict, within this analytical frame? We know that there have been terrorist waves in the Euro-American centered world-system in the past, most recently the string of anarchist attacks in Europe at the end of the 19th century and the beginning of the 20th (Joll 1979). Bergesen and Lizardo (2005) have argued that this last wave was a product of the hegemonic transition from Britain to the United States finalized after the wars of 1914-45. While most of those terrorist attacks represented examples of domestic terrorism, some of the most notable cases (especially those concerned with the assassination of famous political representatives) produced international reverberations (e.g., the assassination of the Archduke Franz Ferdinand on June 28, 1914 by Gavrillo Princip a member of the Young Bosnians, an organization dedicated to pan-Slavic autonomy).

Therefore it is reasonable to hypothesize that terrorism may also be characterized by a recurrence connected with the cycles of the decline and succession in the hegemonic sequence (Bergesen and Lizardo 2005). From this perspective, the primary factor to keep in mind may be the synchronization of two cyclical patterns: one having to do with the spread of non-state violence producing organizations targeting states in the system and the other having to do with recurrent states of stability and instability in the system of states itself. High levels of terrorist 
activity may only have repercussions for the interstate system when the system is closer to a state of "chaos" (Arrighi and Silver 1999), and may have little global impact when a hegemon is able to produce system-level order (Modelski and Thompson 1996). The present conditions are particularly dangerous in this respect (Bergesen and Lizardo 2005).

Nevertheless, the anarchist terrorist attacks of the 19th century seem to pale in comparison to incidents such as $9 / 11$. This seems to suggest that there is a qualitative difference between modern forms of terrorism and similar incidents from the past. We can explain this apparent divergence by pointing to world systemic trends: linear, progressive tendencies endogenous to the interstate system (the imagery of the trend can be combined with that of the cycle to lead to the blended concept of a spiral [Boswell and Chase-Dunn 2000]). The most relevant of these constitute the increasing integration among the actors in the world system facilitated by developments in communications and transportation technology. Technological advances also increase the availability and destructiveness of weapons of war. ${ }^{18}$ Although we must be wary of reducing the differences between modern and pre-modern terrorism purely to technological factors (Rapoport 1984).

During the 19th century anarchist wave for example, international terrorism almost always took the exclusive form of high-profile assassinations, while domestic terrorism involved the targeting of civilians (Joll 1979). However, this apparent operational division between the two forms of terrorism had more to do with the logistic difficulties faced by international terrorists due to their limited access to technological resources, than with some inherent difference between the two. In contrast, given the facilitation of mobility and access produced by recent technological advancements, modern domestic terrorism is as likely to consist of the assassination of high profile individuals as modern international terrorism is to be characterized by attacks on civilians who are seen as representatives of the target country, both by way of terrorists traveling to the country of interest (i.e. $9 / 11, .3 / 11$, the London Bombings) or citizens from those countries being attacked in foreign sites. ${ }^{19}$ Given that both military (weapons) and non-military (communications and transportation) technology has increased the reach and ability of terrorists to inflict damage on civilian populations, we should expect this type of terrorism, both in its domestic and international forms, to be the most severe form that the phenomenon will take during this transitional period.

\section{REFERENCES}

Alimi, Eitan Y. 2006. "Contextualizing Political Terrorism: A Collective Action Perspective for Understanding the Tanzim." Studies in Conflict \& Terrorism 29:263-283.

Arrighi, Giovanni and Beverly J. Silver. 1999. Chaos and Governance in the Modern World System. Minneapolis: University of Minnesota Press.

\footnotetext{
${ }^{18}$ This produces a situation in which national actors must now worry not only about betweennation competition for military advantage, but also of the prospect of infra-national entities obtaining access to mass destruction resources previously monopolized by national and supranational actors.

${ }^{19}$ Note that this is a statement about severity, not incidence. In terms of frequency, we should expect both assassinations and civilian attacks to occur at similar rates.
} 
Bergesen, Albert J. 1985. "Cycles of War in the Reproduction of the World-Economy." Pp. 113131 in Rhythms in Politics and Economics, edited by W. R. Thompson and P. M. Johnson. New York: Praeger.

. 2000. "Postmodernism Explained." Pp. 181-192 in A World-Systems Reader: New Perspectives On Gender, Urbanism, Cultures, Indigenous Peoples, And Ecology, edited by T. D. Hall. Lanham, MD: Rowman and Littlefield.

. 2007. "Three-Step Model of Terrorist Violence." Mobilization: An International Quarterly 12:111-118.

Bergesen, Albert J. and Ronald Schoenberg. 1980. "Long Waves of Colonial Expansion and Contraction, 1415-1969." Pp. 231-277 in Studies of the Modern World System, edited by A. J. Bergesen. New York: Academic Press.

Bergesen, Albert J. and Yi Han. 2005. "New Directions for Terrorism Research." International Journal of Comparative Sociology 46:133-151.

Bergesen, Albert J. and Omar Lizardo. 2005. "Terrorism and Hegemonic Decline." Pp. 227-240 in Hegemonic Decline: Present and Past, edited by J. Friedman and C. Chase-Dunn. Boulder, CO: Paradigm Publishers.

Black, Donald. 2004. "The Geometry of Terrorism." Sociological Theory 22:14-25.

Boli, John and George M. Thomas. 1999. Constructing World Culture. Stanford: Stanford University Press.

Bornschier, Volker and Christopher Chase-Dunn. 1998. The Future of Global Conflict. London: Sage.

Boswell, Terry and Christopher Chase-Dunn. 2000. The Spiral of Capitalism and Socialism: Toward Global Democracy: Lynne Rienner Publishers.

Boswell, Terry and Mike Sweat. 1993. "Hegemony, Long Waves and Major Wars: A Time Series Analysis of Systemic Dynamics, 1496-1967." International Studies Quarterly 35:123149.

Carr, Caleb. 2001. The Lessons of Terror. New York: Random House.

Chalk, Peter. 1999. "The Evolving Dynamic of Terrorism in the 1990s." Australian Journal of International Affairs 53:151-167.

Chase-Dunn, Christopher K. 1998. Global Formation: Structures of the World-Economy. Lanham, MD: Rowman and Littlefield.

Chase-Dunn, Christopher K. and Thomas D Hall. 1997. Rise and Demise: Comparing WorldSystems. Boulder, CO: Westview Press.

Chase-Dunn, Christopher and Joan Sokolovsky. 1983. "Interstate Systems, World-Empires and the Capitalist World-Economy." International Studies Quarterly 27:357-367.

Chomsky, Noam. 2001. 9-11. New York: Seven Stories Press.

Clemens, Elisabeth S. 1996. "Organizational form as frame: Collective identity and political strategy in the American labor movement." Pp. 205-226 in Comparative Perspectives on Social Movements: Opportunities, Mobilizing Structures and Cultural Framings, edited by D. McAdam, J. D. McCarthy, and M. Zald. Cambridge: Cambridge University Press.

Cooper, H. H. A. 2001. "Terrorism: The Problem of Definition Revisited." American Behavioral Scientist 44:881-893.

Cronin, Audrey Kurth. 2003. "Behind the Curve: Globalization and International Terrorism." International Security 27:30-58. 
Davenport, Christian. 1995. "Multi-Dimensional Threat Perception and State Repression: An Inquiry into Why States Apply Negative Sanctions." American Journal of Political Science, 39:683-713.

de la Calle, Luis and Ignacio Sánchez-Cuenca. 2006. "The Production Of Terrorist Violence: Analyzing Target Selection within The IRA And ETA." Center for Advanced Study in the Social Sciences Working Paper 230.

Durkheim, Emile. 1997[1933]. The Division of Labor in Society. New York: The Free Press.

Enders, Walter and Todd Sandler. 2002. "Patterns of Transnational Terrorism, 1970-1999: Alternative Time-Series Estimates." International Studies Quarterly 46:145-165.

Foucault, Michel. 1977. Discipline and Punish: The Birth of the Prison. Translated by A. Sheridan. New York: Vintage.

Friedman, Jonathan. 1994. Cultural Identity and Global Process. London: Sage.

Gibbs, Jack P. 1989. "Conceptualization of Terrorism." American Sociological Review 54:329340.

Giddens, Anthony. 1987. The Nation-State and Violence. Berkeley: University of California Press.

Gilpin, Robert. 1981. War and Change in World Politics. Cambridge: Cambridge University Press.

Goldstein, Joshua S. 1988. Long Cycles: Prosperity and War in the Modern Age. New Haven: Yale University Press.

Goodwin, Jeff. 2006. "A Theory of Categorical Terrorism." Social Forces 84:2027-2046. . 2007. "'The Struggle Made Me a Nonracialist": Why There was so Little Terrorism in the Antiapartheid Struggle." Mobilization: An International Quarterly 12:193-203.

Graham, Stephen. 2004. Cities, War, and Terrorism: Towards an Urban Geopolitics By Stephen Graham. Malden: Blackwell.

Hannan, Michael T. and John Freeman. 1986. "Where Do Organizational Forms Come from?" Sociological Forum:50-72.

Hess, Henner. 2003. "Like Zealots and Romans: Terrorism and Empire in the 21st Century." Crime, Law and Social Change 39:339-357.

Hironaka, Ann. 2005. Neverending Wars: The International Community, Weak States, and the Perpetuation of Civil War. Cambridge: Harvard University Press.

Hoffman, Bruce. 1998. Inside Terrorism. New York: Columbia University Press. . 2002. "Rethinking Terrorism and Counterterrorism Since 9/11." Studies in Conflict and Terrorism 25:303-316.

Jenkins, Brian Michael. 2001. "Terrorism and Beyond: A 21st Century Perspective." Studies in Conflict and Terrorism 24:321-327.

Johnson, Chalmers. 2003. Blowback: The Costs and Consequences of American Empire. New York: Metropolitan Books.

Joll, James. 1979. The Anarchists. London: Methuen.

Juergensmeyer, Mark. 2001. Terror In The Mind Of God: The Global Rise Of Religious Violence. Berkeley: University of California Press.

Kennedy, Paul M. 1987. The Rise and Fall of the Great Powers. New York: Random House.

Levy, Jack S. 1985. "Theories of General War." World Politics 37:344-374.

Lewis, David K. 1969. Convention: A Philosophical Study. Cambridge: Harvard University Press. 
Li, Quan and Drew Schaub. 2004. "Economic Globalization and Transnational Terrorism: A Pooled Time-Series Analysis." The Journal of Conflict Resolution 48:230-258.

Lichbach, Mark Irving, Christian Davenport, and Dave Armstrong. 2004. "Contingency, Inherency, and the Onset of Civil War." Unpublished Manuscript, University Of Maryland.

Lizardo, Omar. 2006. "The effect of economic and cultural globalization on anti-U.S. transnational terrorism: 1971-2000." Journal of World Systems Research 12:149-186.

Mann, Michael. 1986. The Sources of Social Power. Cambridge: Cambridge University Press.

March, James G. and Johan P. Olsen. 1989. Rediscovering Institutions. New York: Free Press.

Marshall, T. H. 1950. Citizenship and social class, and other essays. Cambridge: Cambridge University Press.

Martin, John Levi. 2005. " The objective and subjective rationalization of war." Theory and Society 34:229-275.

Mason, T. David and Dale A. Krane. 1989. "The Political Economy of Death Squads: Toward a Theory of the Impact of State-Sanctioned Terror." International Studies Quarterly 33:175-198.

Meyer, John W., John Boli, George M. Thomas, and Francisco O. Ramirez. 1997. "World Society and the Nation-State." American Journal of Sociology 103:144-181.

Meyer, John.W., John Boli, and George.M. Thomas. 1994. "Ontology and Rationalization in the Western Cultural Account." Pp. 9-27 in Institutional Environments and Organizations, edited by W. R. Scott and J. W. Meyer. Thousand Oaks, CA: Sage Publications.

Mills, C. Wright. 1940. "Situated Actions and Vocabularies of Motive." American Sociological Review 5:904-913.

Modelski, George and William R Thompson. 1996. Leading Sectors and World Powers. Columbia, SC: University of South Carolina Press.

Naim, Moises. 2003. "The Five Wars of Globalization." Foreign Policy. 134:28-38.

O'Sullivan, Noel. 1986. "Terrorism, Ideology and Democracy." Pp. 3-26 in Terrorism, Ideology \& Revolution, edited by N. O'Sullivan. Brighton, Sussex: Wheatsheaf Books.

Oliverio, Annamarie. 1998. The State Of Terror. Albany: State University of New York Press.

Olzak, Susan. 2006. The Global Dynamics of Racial and Ethnic Mobilization. Stanford: Stanford University Press.

Pape, Robert A. 2003. "The Strategic Logic of Suicide Terrorism." American Political Science Review 97:343-361.

Pion-Berlin, David and George A. Lopez. 1991. "Of Victims and Executioners: Argentine State Terror, 1975-1979." International Studies Quarterly 35:63-86.

Poggi, Gianfranco. 1990. The State: Its Nature, Development, and Prospects. Stanford: Stanford University Press.

Pollins, Brian M. 1996. "Global Political Order, Economic Change, and Armed Conflict: Coevolving Systems and the Use of Force." American Political Science Review 90:103117.

Price, H. Edward. 1977. "The Strategy and Tactics of Revolutionary Terrorism." Comparative Studies in Society and History 19:52-66.

Rapoport, David C. 1984. "Fear and Trembling: Terrorism in Three Religious Traditions." American Political Science Review 78:658-677. 1988. "Messianic Sanctions for Terror." Comparative Politics 20:195-213. 
Robinson, William I. 2001. "Social theory and globalization: The rise of a transnational state." Theory and Society 30:157-200.

Ruby, Charles L. 2002. "The Definition of Terrorism." Analyses of Social Issues and Public Policy 2:9-14.

Sanguinetti, Gianfranco. 1982. On Terrorism and the State. London: Chronos Press.

Schmid, Alex Peter and A. J. Jongman. 1988. Political Terrorism. New York: Transaction Books.

Scott, W. Richard. 2001. Institutions and organizations. Thousand Oaks, CA: Sage.

Senechal de la Roche, Roberta. 1996. "Collective Violence as Social Control." Sociological Forum 11:97-128.

Stern, Jessica. 1999. The Ultimate Terrorists. Cambridge: Harvard University Press.

Thomas, George M. and John W. Meyer. 1984. "The Expansion of the State." Annual Review of Sociology 10:461-482.

Tilly, Charles. 1990. Coercion, capital, and European states AD 990-1992. Malden: Blackwell. . 2004. "Terror, Terrorism, Terrorists." Sociological Theory 22:5-13.

Tosini, Domenico. 2007. "Sociology of Terrorism and Counterterrorism: A Social Science Understanding of Terrorist Threat." Sociology Compass 1:664-681.

Vinci, Anthony. 2008. "Anarchy, Failed States, and Armed Groups: Reconsidering Conventional Analysis." International Studies Quarterly 52:295-314.

Wallerstein, Immanuel. 1983. Historical Capitalism. London: Verso.

Weick, Karl E. 1995. Sensemaking in Organizations. Thousand Oaks, CA: Sage.

Wilkinson, Paul. 1977. Terrorism and the Liberal State. New York: John Wiley. 


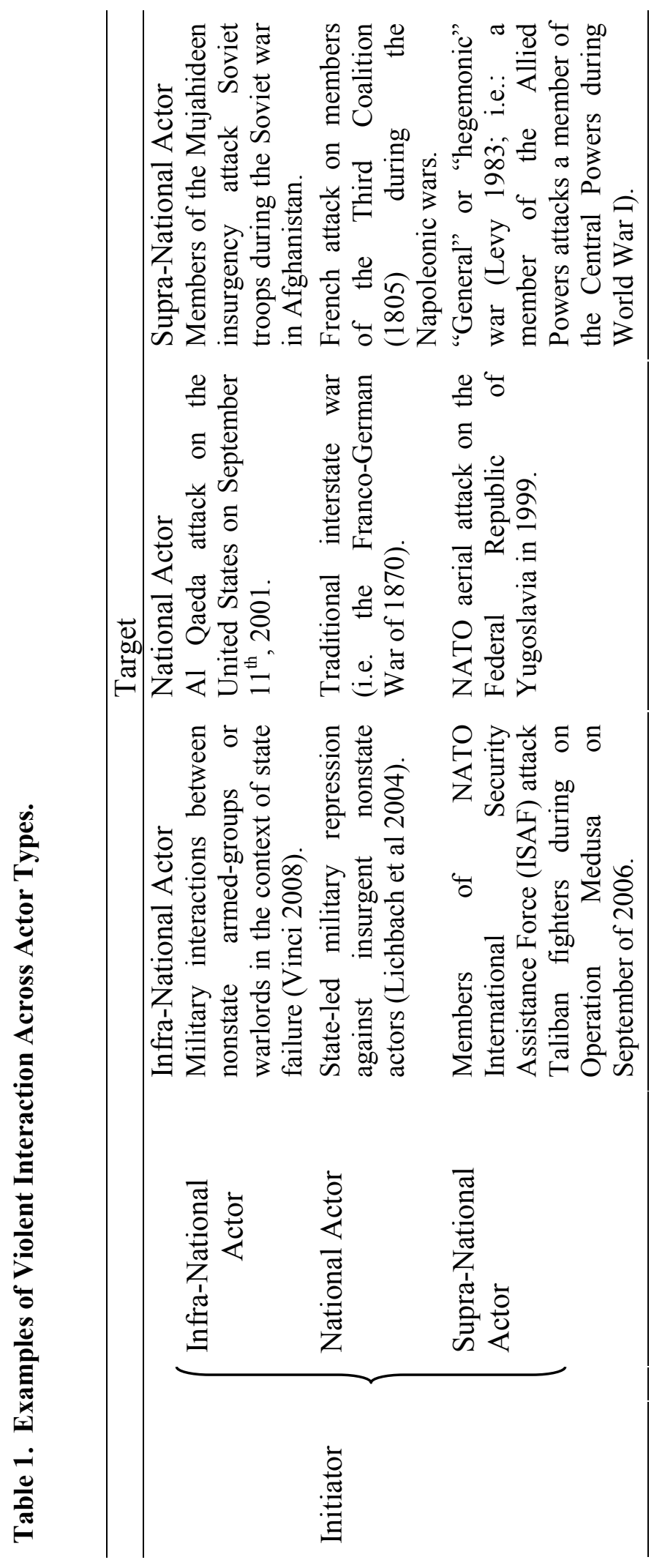

